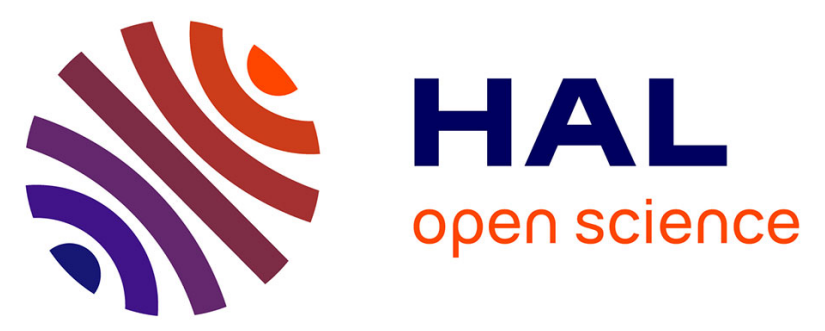

\title{
Influence of partial dealumination of BEA zeolites on physicochemical and catalytic properties of AgAlSiBEA in H2-promoted SCR of NO with ethanol
}

Nataliia O. Popovych, Pavlo I. Kyriienko, Sergiy O. Soloviev, Svitlana M. Orlyk, Stanislaw Dzwigaj

\section{To cite this version:}

Nataliia O. Popovych, Pavlo I. Kyriienko, Sergiy O. Soloviev, Svitlana M. Orlyk, Stanislaw Dzwigaj. Influence of partial dealumination of BEA zeolites on physicochemical and catalytic properties of AgAlSiBEA in H2-promoted SCR of NO with ethanol. Microporous and Mesoporous Materials, 2016, 226, pp.10-18. 10.1016/j.micromeso.2015.12.031 . hal-01259919

\section{HAL Id: hal-01259919 \\ https://hal.sorbonne-universite.fr/hal-01259919}

Submitted on 21 Jan 2016

HAL is a multi-disciplinary open access archive for the deposit and dissemination of scientific research documents, whether they are published or not. The documents may come from teaching and research institutions in France or abroad, or from public or private research centers.
L'archive ouverte pluridisciplinaire HAL, est destinée au dépôt et à la diffusion de documents scientifiques de niveau recherche, publiés ou non, émanant des établissements d'enseignement et de recherche français ou étrangers, des laboratoires publics ou privés. 
Influence of partial dealumination of BEA zeolites on physicochemical and catalytic properties of AgAISiBEA in $\mathrm{H}_{2}$-promoted SCR of $\mathrm{NO}$ with ethanol

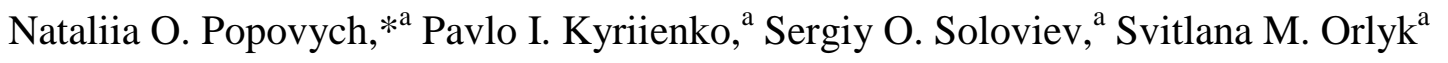
and Stanislaw Dzwigaj*b,c

${ }^{a}$ L.V. Pisarzhevskii Institute of Physical Chemistry of the National Academy of Sciences of Ukraine, 31 Prosp. Nauky, 03028 Kyiv, Ukraine Fax: +38 0445256590.

b Sorbonne Universités, UPMC Univ Paris 06, UMR 7197, Laboratoire de Réactivité de Surface, F-75005 Paris, France. E-mail: stanislaw.dzwigaj@upmc.fr

${ }^{\text {c }}$ CNRS, UMR 7197, Laboratoire de Réactivité de Surface, F-75005, Paris, France

Figures: 10

Keywords: hydrogen, SCR, NO, silver, BEA zeolite

* Corresponding authors:

N. Popovych, E-mail address: natalie.popovych@ukr.net, fax: +38 (044) 5256590.

S. Dzwigaj, E-mail address: stanislaw.dzwigaj@upmc.fr, fax: +33 0144276033. 


\begin{abstract}
The two-step postsynthesis method allows obtaining AlSiBEA zeolites with different degree of dealumination ( $\mathrm{Si} / \mathrm{Al}=100$ and 200). Physicochemical properties (crystallinity, hydroxyl group coverage, acidic sites and nature of silver species) of AlSiBEA and AgAlSiBEA were investigated by XRD, DR UV-vis, XPS, TEM and FT-IR with CO and pyridine as probe molecules. Catalytic properties of the zeolites were studied in the process of selective reduction of NO with ethanol in the presence of hydrogen in the reaction mixture. It was shown that level of $\mathrm{H}_{2}$-promoting effect on the SCR-process depends on the dealumination degree of Agcontaining BEA zeolites and greater effect is observed for the catalysts with higher concentration of Lewis acidic sites.
\end{abstract}




\section{Introduction}

Nitrogen oxides $\left(\mathrm{NO}_{\mathrm{x}}\right)$ abatement in exhaust gases of lean-burn and diesel engines remains a target for environmental catalysis research. Metal-containing zeolites are known to be promising catalysts for selective catalytic reduction (SCR) of $\mathrm{NO}_{\mathrm{x}}$ with hydrocarbons and oxygenates [1]. Activity of zeolite catalysts depends on the nature of added metal $(\mathrm{Cu}, \mathrm{Fe}, \mathrm{Co}$, $\mathrm{Ag}$ ) as well as on the framework type (MFI, BEA, MOR, FAU) [2-4]. Interest in silvercontaining catalysts was stimulated after the finding that addition of hydrogen into the reaction mixture enhances the selective reduction of $\mathrm{NO}_{\mathrm{x}}$ [5]. The origin of this effect is still under debate, i.e., the role of $\mathrm{H}_{2}$ in the reaction mechanism and structural changes of silver active sites [6-15]. It is most likely that in order to increase the rate of $\mathrm{NO}_{\mathrm{x}}$ conversion hydrogen must accelerate a rate-determining step of the reaction [6,7]. The enhanced activity after $\mathrm{H}_{2}$ addition was assigned to the formation of the nitrite species that are more reactive than adsorbed nitrate species in $\mathrm{C}_{3} \mathrm{H}_{6}-\mathrm{SCR}$ reaction on $\mathrm{Ag} / \mathrm{Al}_{2} \mathrm{O}_{3}$ [7,8]. Other way of hydrogen effect was suggested to be the formation of active oxygen species on $\mathrm{Ag}$ clusters on $\mathrm{Ag} / \mathrm{Al}_{2} \mathrm{O}_{3}$ and $\mathrm{Ag}$-MFI catalysts $[9,10]$, which promote partial oxidation of hydrocarbons to surface acetate [11] or enolic species [12]. Formation of the key intermediate of isocyanate from cyanide was also considered as the rate-determining step and was suggested to be promoted by hydrogen [6,13-15].

However, silver ions and clusters were considered only as active sites of the hydrogenpromoted SCR of $\mathrm{NO}_{\mathrm{x}}$ with hydrocarbons or oxygenates and influence of the acidic sites has not been taken into consideration. It was only proposed [16] that variation in catalytic activity of Agcontaining zeolites in $\mathrm{C}_{3} \mathrm{H}_{8}$-SCR of $\mathrm{NO}$ in the presence of $\mathrm{H}_{2}$ arises from the support effect on the ratio of $\mathrm{Ag}$ species, which was shifted to cationic side with the increase of amount and strength of acidic sites in zeolites. The effect of acidic properties of $\mathrm{Ag} / \mathrm{Al}_{2} \mathrm{O}_{3}$ catalysts on their activity in the SCR of $\mathrm{NO}_{\mathrm{x}}$ with hydrocarbons or oxygenates was highlighted in several recent studies [17-19]. 
In a previous work [20], we have shown that promoting $\mathrm{H}_{2}$-effect in the SCR of NO with ethanol is observed in the presence of AgBEA (with $\mathrm{Si} / \mathrm{Al}$ ratio equal to 12.5), whereas it is almost absent on Ag-containing catalysts based on dealuminated BEA ( $\mathrm{Si} / \mathrm{Al}=1000)$. It was concluded that a necessary condition for $\mathrm{H}_{2}$-effect is the presence of silver clusters in close proximity to strong Lewis acidic sites (LAS) in the zeolite catalysts. Therefore, it is expedient to study the influence of intermediate degree of dealumination $(12.5<\mathrm{Si} / \mathrm{Al}<1000)$ on the appearance of $\mathrm{H}_{2}$-effect.

For this purpose Ag-containing partially dealuminated BEA zeolites (with Si/Al ratio of 100 and 200) were prepared using the two-step postsynthesis method [21-24]. The present work aimed to investigate the influence of partial dealumination of AgBEA zeolites on their physicochemical properties (crystallinity, acidity, nature of silver species) and catalytic performance in the $\mathrm{H}_{2}$-promoted SCR of NO with ethanol.

\section{Experimental}

\subsection{Catalysts preparation}

Silver containing BEA zeolite was prepared by the two-step postsynthesis method: in the first step, TEABEA zeolite provided by RIPP (China) was treated in 6 or $8 \mathrm{~mol} \cdot \mathrm{L}^{-1} \mathrm{HNO}_{3}$ aqueous solution $(353 \mathrm{~K})$ to obtain partially dealuminated supports AlSiBEA $(\mathrm{Si} / \mathrm{Al}=100)$ or AlSiBEA $(\mathrm{Si} / \mathrm{Al}=200)$ with the vacant $\mathrm{T}$-atom sites $(\mathrm{T}=\mathrm{Al})$. Then the suspension was recovered by centrifugation, washed with distilled water and dried at $353 \mathrm{~K}$. The resulting partially dealuminated zeolites were labeled as $\operatorname{AlSiBEA}(100)$ and $\operatorname{AlSiBEA}(200)$, where $\mathrm{Si} / \mathrm{Al}$ ratio was marked in parenthesis.

To prepare Ag-containing zeolites, $2 \mathrm{~g}$ of AlSiBEA $(\mathrm{Si} / \mathrm{Al}=100)$ and AlSiBEA $(\mathrm{Si} / \mathrm{Al}=$ 200) was firstly stirred under aerobic conditions for $2 \mathrm{~h}$ at $298 \mathrm{~K}$ in $200 \mathrm{~mL}$ of $\mathrm{AgNO}_{3}($ Fluka silver nitrate with high $\mathrm{Ph}$ Eur purity with $\mathrm{Ag}>99.8 \%)$ aqueous solution $(\mathrm{pH}=2.3)$ with different concentrations of $0.9,2.7$ and $5.4 \cdot 10^{-3} \mathrm{~mol} \cdot \mathrm{L}^{-1}$ to obtain the zeolites with various $\mathrm{Ag}$ 
content. Then the suspension was stirred in evaporator under vacuum of a water pump for $2 \mathrm{~h}$ in air at $353 \mathrm{~K}$ until the water was evaporated. The resulting solid containing $0.5,1.5$ and $3.0 \mathrm{Ag}$ wt $\%$ were labeled as $\operatorname{Ag}_{0.5} \operatorname{AlSiBEA}(100), \operatorname{Ag}_{1.5} \operatorname{AlSiBEA}(100)$ and $\operatorname{Ag}_{3.0} \operatorname{AlSiBEA}(100)$ or $\mathrm{Ag}_{0.5} \mathrm{AlSiBEA}(200), \mathrm{Ag}_{1.5} \mathrm{AlSiBEA}(200)$ and $\mathrm{Ag}_{3.0} \mathrm{AlSiBEA}(200)$, respectively, with Si/Al ratio marked in parenthesis.

Preparation and physicochemical properties of AgAlBEA and AgSiBEA were described earlier [25,26]. To prepare AgAlBEA zeolite, firstly, the TEABEA zeolite was calcined at $823 \mathrm{~K}$ for $15 \mathrm{~h}$ to obtain $\mathrm{AlBEA}(\mathrm{Si} / \mathrm{Al}=12.5)$ and secondly, the latter was impregnated with $\mathrm{AgNO}_{3}$ aqueous solution. AgSiBEA zeolite was prepared by the two-step postsynthesis method: treatment of TEABEA zeolite in $13 \mathrm{~mol} \cdot \mathrm{L}^{-1} \mathrm{HNO}_{3}$ aqueous solution $(4 \mathrm{~h}, 353 \mathrm{~K})$ in the first step to obtain a dealuminated $(\mathrm{Si} / \mathrm{Al}=1000)$ and organic-free SiBEA support and stirring of SiBEA under aerobic conditions for $2 \mathrm{~h}$ at $298 \mathrm{~K}$ in $200 \mathrm{ml}$ of aqueous $\mathrm{AgNO}_{3}$ solution followed by stirring in evaporator under vacuum of the water pump for $2 \mathrm{~h}$ in air at $353 \mathrm{~K}$ until evaporation of the water.

\subsection{Catalysts characterization}

X-Ray Fluorescence chemical analysis was performed at room temperature on a SPECTRO X-LabPro apparatus.

Powder X-ray diffraction (XRD) was recorded at room temperature and ambient atmosphere on a Bruker D8 Advance diffractometer using the $\mathrm{CuK} \alpha$ radiation $(\lambda=154.05 \mathrm{pm})$.

Analysis of the acidic properties of samples was performed by adsorption of pyridine and CO followed by Fourier transform infrared spectroscopy (FT-IR). Before analysis, the samples were pressed at $\approx 1$ ton $\cdot \mathrm{cm}^{-2}$ into thin wafers of ca. $10 \mathrm{mg} \cdot \mathrm{cm}^{-2}$ and placed inside the IR cell.

Before $\mathrm{CO}$ adsorption experiment, the wafers were activated by calcination at $723 \mathrm{~K}$ for 2 $\mathrm{h}$ in flowing $2.5 \% \mathrm{O}_{2} / \mathrm{Ar}$ and then outgassed at $573 \mathrm{~K}\left(10^{-3} \mathrm{~Pa}\right)$ for $1 \mathrm{~h}$. Following thermal treatment, the samples were cooled down to $100 \mathrm{~K}$. CO was introduced in increasing amounts up to an equilibrium pressure of $133 \mathrm{~Pa}$. Infrared spectra were recorded using a Bruker Vertex 70 
spectrometer (resolution $-2 \mathrm{~cm}^{-1}, 128$ scans). The spectra were obtained after subtraction of the spectrum recorded after calcination and prior to $\mathrm{CO}$ adsorption.

Before pyridine adsorption/desorption experiments, the wafers were activated by calcination in static conditions at $773 \mathrm{~K}$ for $1 \mathrm{~h}$ in $\mathrm{O}_{2}\left(2 \cdot 10^{4} \mathrm{~Pa}\right.$ ) (or in $\mathrm{H}_{2}$ flow) and then outgassed under secondary vacuum at $673 \mathrm{~K}\left(10^{-3} \mathrm{~Pa}\right)$ for $1 \mathrm{~h}$. The wafers were contacted at 423 $\mathrm{K}$ with gaseous pyridine. The spectra were recorded after pyridine desorption at 423, 573 and $673 \mathrm{~K}$ using Spectrum One FT-IR spectrometer (resolution $-1 \mathrm{~cm}^{-1}, 12$ scans). The reported spectra were obtained after subtraction of the spectrum recorded after calcination and prior to pyridine adsorption.

Diffuse reflectance (DR) UV-vis spectra were recorded at ambient atmosphere on a Cary 5000 Varian spectrometer equipped with a double integrator with polytetrafluoroethylene as reference.

\subsection{Catalytic tests}

Catalytic activity tests were carried out in a fixed-bed flow quartz reactor at atmospheric pressure. Samples with grains of $0.5-1.0 \mathrm{~mm}\left(0.5 \mathrm{~cm}^{3}, \approx 0.3 \mathrm{~g}\right)$ were loaded into the reactor. Gas feed for the reaction was $500 \mathrm{ppm} \mathrm{NO}, 1000 \mathrm{ppm} \mathrm{C}_{2} \mathrm{H}_{5} \mathrm{OH}, 10 \% \mathrm{O}_{2}, 0.5 \% \mathrm{H}_{2}$ in $\mathrm{He}$ with the gas hour space velocity of $24,000 \mathrm{~h}^{-1}$. The gas feed was adjusted by mass-flow controllers (Chromatek-Crystal FGP). Before reaction, the catalyst was heated to $773 \mathrm{~K}$ at a heating rate of 20 degrees $\cdot \min ^{-1}$ in a flow of $\mathrm{O}_{2} / \mathrm{He}$ (or $\mathrm{H}_{2} / \mathrm{He}$ when hydrogen was added to the reaction mixture) and held for $1 \mathrm{~h}$, then cooled to $453 \mathrm{~K}$ with a further step-heating in reaction gas feed to a temperature of conversion measurement. The steady-state activity was measured after $30 \mathrm{~min}$ reaction at a certain temperature. The temperature was controlled through an Autonics TZN4S temperature controller using a chromel-alumel thermocouple. The concentration of NO was continuously monitored using a chemiluminescence gas analyzer (344HL04, Ukraine). The products were analyzed by gas chromatograph (TCD) (Kristallyuks 4000M, Metachrom, Russia) with a CaA column (for $\mathrm{NO}, \mathrm{N}_{2}, \mathrm{CO}$ ) and a Polisorb-1 column (for $\mathrm{N}_{2} \mathrm{O}, \mathrm{CO}_{2}, \mathrm{C}_{2} \mathrm{H}_{4}$, ethanol). 
Catalytic activity was characterized by $\mathrm{NO}$ conversion to $\mathrm{N}_{2}$ and temperatures of its achievement.

\section{Results and Discussion}

\subsection{Characterization of AlSiBEA and AgAlSiBEA}

\subsubsection{Crystallinity of the samples}

X-ray diffractograms of AlSiBEA(100) and AlSiBEA(200), i.e., after partial removal of aluminium atoms, are similar with TEABEA zeolite calcined at $823 \mathrm{~K}$ for $15 \mathrm{~h}$ (AlBEA(12.5)) $[25,26]$, suggesting that the dealumination does not significantly affect the structure and crystallinity of BEA zeolite are preserved (Fig. 1).

A narrow diffraction peak near $22.5^{\circ}$ is generally taken as evidence of lattice contraction/expansion of the BEA structure [27,28]. The $d_{302}$ spacing, calculated from the corresponding $2 \theta$ value, decreases from $3.950 \AA$ (AlBEA with $2 \theta$ of $22.48^{\circ}$ ) [26] to $3.947 \AA$ $\left(\operatorname{AlSiBEA}(100)\right.$ with $2 \theta$ of $\left.22.50^{\circ}\right)$ and to $3.940 \AA$ (AlSiBEA(200) with $2 \theta$ of $\left.22.54^{\circ}\right)$ suggesting a matrix contraction, consistent with the removal of aluminium from the zeolite framework.

Upon introduction of 1.5 and $3.0 \mathrm{Ag}$ wt $\%$ into $\operatorname{AlSiBEA}(100)$ the $\mathrm{d}_{302}$ spacing increases from $3.947 \AA$ to $3.950 \AA\left(\mathrm{Ag}_{1.5} \mathrm{AlSiBEA}(100)\right.$ with $2 \theta$ of $\left.22.48^{\circ}\right)$ and to $3.956 \AA$ $\left(\mathrm{Ag}_{3.0} \mathrm{AlSiBEA}(100)\right.$ with $2 \theta$ of $\left.22.45^{\circ}\right)$ (Fig. $\left.1 \mathrm{~A}\right)$. For the sample with the Si/Al ratio equal to 200 (Fig. 1B), $\mathrm{d}_{302}$ spacing increases after silver introduction from $3.940 \AA$ to $3.945 \AA$ $\left(\mathrm{Ag}_{1.5} \operatorname{AlSiBEA}(200)\right.$ with $2 \theta$ of $\left.22.51^{\circ}\right)$ and to $3.947 \AA\left(\operatorname{Ag}_{3.0} \operatorname{AlSiBEA}(200)\right.$ with $2 \theta$ of $\left.22.50^{\circ}\right)$. This increase can be taken as an evidence of framework expansion of the BEA structure and suggests incorporation of silver ions into the vacant $\mathrm{T}$ atom sites of in the framework of AlSiBEA zeolite, in line with earlier reports [21,29].

\subsubsection{FT-IR characterization of the hydroxyl groups}

$\operatorname{AlSiBEA}(100), \operatorname{Ag}_{1.5} \operatorname{AlSiBEA}(100), \operatorname{AlSiBEA}(200)$ and $\operatorname{Ag}_{1.5} \operatorname{AlSiBEA}(200)$ zeolites have been investigated by FT-IR spectroscopy in the range of vibration of $\mathrm{OH}$ groups (Fig. 2). 
As was shown earlier $[25,26]$, the FT-IR spectrum of AlBEA(12.5) exhibits four main IR bands due to the $\mathrm{OH}$ stretching modes of Al-OH (bands at 3781 and $3667 \mathrm{~cm}^{-1}$ ), zeolite acidic hydroxyls Al-O(H)-Si (band at $3615 \mathrm{~cm}^{-1}$ ) and $\mathrm{Si}-\mathrm{OH}$ groups (band at $3750 \mathrm{~cm}^{-1}$ with a shoulder at $3740 \mathrm{~cm}^{-1}$ ). The treatment of TEABEA zeolite by aqueous acid nitric solution leads to the partial dealumination of the framework as evidenced by the absence of bands at 3781 and 3667 $\mathrm{cm}^{-1}$ and presence of the band at $3615-3630 \mathrm{~cm}^{-1}$ on the spectra of AlSiBEA(100) and AlSiBEA(200) (Fig. 2). Bands at $3709-3714 \mathrm{~cm}^{-1}$ related to terminal internal silanol groups and broad bands at $3490-3520 \mathrm{~cm}^{-1}$ due to $\mathrm{H}$-bonded $\mathrm{Si}-\mathrm{OH}$ groups evidence creation of vacant Tatom sites associated with silanol groups upon partial removal of framework aluminium, in line with earlier assignments [21,29].

Upon introduction of $1.5 \mathrm{Ag}$ wt \% in $\operatorname{AlSiBEA}(100)$ and $\operatorname{AlSiBEA}(200)$ intensity of the bands at $3615-3630 \mathrm{~cm}^{-1}$ and $3490,3529 \mathrm{~cm}^{-1}$ decreased indicating that some of the Al-O(H)-Si and hydrogen bonded $\mathrm{Si}-\mathrm{OH}$ groups have been consumed during their reaction with silver precursor.

\subsubsection{Characterization of acidic sites: FT-IR spectroscopy with $\mathrm{CO}$ and pyridine}

To determine the nature, number and strength of acidic sites in the partially dealuminated BEA samples FT-IR spectra of adsorbed CO (Figs. 3-4) and pyridine (Fig. 5) as probe molecules were taken.

Difference spectra between FT-IR spectra in $\mathrm{OH}$ stretching region recorded after and before $\mathrm{CO}$ adsorption on $\operatorname{AlSiBEA}(100), \quad \operatorname{Ag}_{1.5} \operatorname{AlSiBEA}(100), \quad \operatorname{AlSiBEA}(200)$ and $\operatorname{Ag}_{1.5} \operatorname{AlSiBEA}(200)$ at $100 \mathrm{~K}$ are given in Fig. 3. The adsorption of $\mathrm{CO}$ at $100 \mathrm{~K}$ (100 Pa equilibrium pressure) leads to appearance of intense positive bands at 3645, 3595, 3445, $3290 \mathrm{~cm}^{-1}$ and negative bands at 3739,3715 and $3615 \mathrm{~cm}^{-1}$. The intensity of the bands at 3645 and $3595 \mathrm{~cm}^{-1}$ quickly decreases during outgassing of $\mathrm{CO}$, while the bands at 3739 and $3715 \mathrm{~cm}^{-}$ ${ }^{1}$ are restored. The observed shift of $94 \mathrm{~cm}^{-1}$ from 3739 to $3645 \mathrm{~cm}^{-1}$ for isolated external Si-OH groups and $120 \mathrm{~cm}^{-1}$ from 3715 to $3595 \mathrm{~cm}^{-1}$ for terminal internal Si-OH groups indicate that 
these silanol groups in all samples have weak acidic character. The low intensity of positive bands at 3445 and $3290 \mathrm{~cm}^{-1}$ related to red shifted bands of perturbed Al-O(H)-Si groups [3032], suggests that only a little amount of these acidic hydroxyls groups occur in the partially dealuminated zeolites.

For $\operatorname{Ag}_{1.5} \operatorname{AlSiBEA}(100)$ and $\operatorname{Ag}_{1.5} \operatorname{AlSiBEA}(200)$ lower intensity of the bands at 3645 , 3595, 3445 and 3290 (absence for $\operatorname{Ag}_{1.5} \operatorname{AlSiBEA}(200)$ ) $\mathrm{cm}^{-1}$ indicates reaction of $\mathrm{Al}-\mathrm{O}(\mathrm{H})-\mathrm{Si}$ and hydrogen bonded $\mathrm{Si}-\mathrm{OH}$ groups with silver precursor.

Figure 4 shows the changes in the carbonyl region when $\mathrm{CO}$ is adsorbed on $\operatorname{AlSiBEA}(100), \operatorname{Ag}_{1.5} \operatorname{AlSiBEA}(100), \operatorname{AlSiBEA}(200)$ and $\operatorname{Ag}_{1.5} \operatorname{AlSiBEA}(200)$. In the case of $\operatorname{AlSiBEA}(100)$ and $\operatorname{AlSiBEA}(200)$ under CO equilibrium pressure of $100 \mathrm{~Pa}$, carbonyl bands are detected at 2175, 2157, 2140 and 2134-2135 $\mathrm{cm}^{-1}$ (Fig. 4, spectrum a). The bands at 2140 and $2134-2135 \mathrm{~cm}^{-1}$ are assigned to weakly bonded physically adsorbed CO [33,34] and disappear first upon outgassing. The next band to disappear is that at $2157 \mathrm{~cm}^{-1}$. It changes simultaneously with the band at $3645 \mathrm{~cm}^{-1}$ allowing assigning $2157 \mathrm{~cm}^{-1}$ band to $\mathrm{CO}$ bonded to silanol groups present in vacant T-atom sites [24]. Further sample outgassing provokes disappearance of the band at $2175 \mathrm{~cm}^{-1}$ (Fig. 4, spectra b-f), typical of CO interacting with bridging Al-O(H)-Si hydroxyls. Low intensity bands at 2185 and $2225 \mathrm{~cm}^{-1}$ (spectra f) correspond to $\mathrm{Al}^{3+}$-CO vibrations with $\mathrm{Al}$ in framework and extraframework positions remained in the zeolite structures after dealumination.

For $\mathrm{Ag}_{1.5} \mathrm{AlSiBEA}(100)$ and $\operatorname{Ag}_{1.5} \operatorname{AlSiBEA}(200)$ four main bands at 2184, 2157, 2140 and 2135-2137 $\mathrm{cm}^{-1}$ appear. The positions of three bands at 2157, 2140, 2135-2137 $\mathrm{cm}^{-1}$ are the same as those observed for $\operatorname{AlSiBEA}(100)$ and $\operatorname{AlSiBEA}(200)$ and can be assigned to $\mathrm{CO}$ interacting with silanol groups (band at $2157 \mathrm{~cm}^{-1}$ ) and to physically bonded CO (bands at 2140 and $\left.2135-2137 \mathrm{~cm}^{-1}\right)$. In contrast, the intensity of the band at $2157 \mathrm{~cm}^{-1}$ for $\operatorname{Ag}_{1.5} \operatorname{AlSiBEA}(100)$ and $\operatorname{Ag}_{1.5} \operatorname{AlSiBEA}(200)$ is much lower than that observed for silver-free zeolites. It proves the consumption of silanol groups as a result of reaction with silver ions. epen incerperation of 
silver ions in the vacant $\mathrm{T}$-atom sites of the zeolites. The decreasing of the intensities of the bands of silanol groups after incerperation of reaction with silver ions in the vacant $\mathrm{T}$-atem sites is accompanied by the appearance of the band at $2184 \mathrm{~cm}^{-1}$ which could be assigned to $v(\mathrm{CO})$ stretching vibration of $\mathrm{Ag}^{+}-\mathrm{CO}$ complexes.

Difference spectra between FT-IR spectra recorded after and before pyridine adsorption on $\operatorname{AlSiBEA}(100), \operatorname{Ag}_{3.0} \operatorname{AlSiBEA}(100), \operatorname{AlSiBEA}(200)$ and $\operatorname{Ag}_{3.0} \operatorname{AlSiBEA}(200)$ are shown in Fig. 5. For $\operatorname{AlSiBEA}(100)$ and $\operatorname{AlSiBEA}(200)$, the bands typical of pyridinium cations are observed at 1638 and $1547 \mathrm{~cm}^{-1}$, indicating the presence of Brønsted acidic sites. These sites are related to the acidic proton of $\mathrm{Al}-\mathrm{O}(\mathrm{H})-\mathrm{Si}$ groups, in line with earlier data obtained for BEA zeolite [24,29].

The bands at 1622 and $1455 \mathrm{~cm}^{-1}$ are related to pyridine interacting with strong Lewis acidic sites $\left(\mathrm{Al}^{3+}\right)$ while the one at $1600 \mathrm{~cm}^{-1}$ corresponds to pyridine interacting with weak Lewis acidic sites, the band $1448 \mathrm{~cm}^{-1}$ could be related to pyridine interacting with weak Lewis acidic sites and/or physisorbed pyridine. The band at $1491 \mathrm{~cm}^{-1}$ corresponds to pyridine interacting with both Brønsted and Lewis acidic sites.

Desorption at increasing temperatures resulted in the appearance of a new band at 1463 $\mathrm{cm}^{-1}$ (Fig. 5, spectra c), which was assigned to iminium ions formed by the attack of protons on the pyridine complex bonded to Lewis acidic sites [35]. However, there is also other possible explanation for the presence of the bands at 1455 and $1463 \mathrm{~cm}^{-1}$ - the band of higher frequency represents Lewis sites of a higher relative acid strength [36]. The adsorption bands of pyridinium cations and pyridine bonded to LAS are present in the FT-IR spectra even after outgassing at $673 \mathrm{~K}$ (Fig. 5, spectra c), suggesting the presence of strong Brønsted and Lewis acidic sites. The difference between FT-IR spectra of pyridine adsorbed on AlSiBEA(100) and AlSiBEA(200) is lower intensity of the bands for $\operatorname{AlSiBEA}(200)$ spectra, indicating the lower concentration of Brønsted and Lewis acidic sites, which are related to number of $\mathrm{Al}$ atoms remaining in BEA zeolite after dealumination. 
The incorporation of silver in AISiBEA(100) and AISiBEA(200) leads to appearance of new bands with high intensity at 1605 and $1450 \mathrm{~cm}^{-1}$, as shown for $\operatorname{Ag}_{3.0} \operatorname{AlSiBEA}(100)$ and $\operatorname{Ag}_{3.0} \operatorname{AlSiBEA}(200)$ in Fig. 5, suggesting the formation of silver Lewis acidic sites. Formation of new LAS after the introduction of silver was also observed for AlBEA(12.5) and SiBEA(1000) zeolites [25,26]. Lower intensity of the bands at 1638,1547 and $1491 \mathrm{~cm}^{-1}$ indicates decrease in concentration of Brønsted acidic sites due to consumption of some $\mathrm{Al}-\mathrm{O}(\mathrm{H})-\mathrm{Si}$ and hydrogen bonded $\mathrm{Si}-\mathrm{OH}$ groups during their reaction with silver precursor. Increase in concentration of Lewis acidic sites after introduction of silver $(3.0 \mathrm{wt} \%)$ in $\operatorname{AlSiBEA}(100)$ is greater than that observed in AlSiBEA(200) (Fig. S1 in Supplementary material). It is likely that higher amount of Lewis acidic sites are formed when they include unsaturated aluminum and silver species.

Fig. 6 shows FT-IR spectra of adsorbed pyridine on $\operatorname{AlSiBEA}(100), \operatorname{Ag}_{3.0} \operatorname{AlSiBEA}(100)$ and $\mathrm{Ag}_{3.0} \mathrm{AlSiBEA}(200)$ zeolites reduced in $\mathrm{H}_{2}$ flow. As could be seen for $\mathrm{AlSiBEA}(100)$ reduction in hydrogen almost does not change the bands corresponding to Brønsted and Lewis acidic sites (Fig. 5A, a and Fig. 6). For reduced $\mathrm{Ag}_{3.0} \mathrm{AlSiBEA}(100)$ and $\mathrm{Ag}_{3.0} \mathrm{AlSiBEA}(200)$ decrease in intensity of the bands at 1450 and $1605 \mathrm{~cm}^{-1}$ is observed as well as increase of band at $1491 \mathrm{~cm}^{-1}$. It is probable that not all $\mathrm{Ag}$ species are reduced with $\mathrm{H}_{2}$ and some amount of silver-containing LAS is remained.

\subsubsection{Nature of silver species}

Silver state in the zeolites was investigated by DR UV-vis, X-ray photoelectron spectroscopy (XPS), and transmission electron microscopy (TEM).

Fig. 7 shows the DR UV-vis spectra of $\operatorname{Ag}_{3.0} \operatorname{AlSiBEA}(100)$ and $\operatorname{Ag}_{3.0} \mathrm{AlSiBEA}(200)$ zeolites after pre-treatment in the conditions of $\mathrm{H}_{2}$-promoted SCR of $\mathrm{NO}$ with ethanol. For both samples there are four main bands at 225, 260, 286 and $412 \mathrm{~nm}$. The absorbance in the region below $250 \mathrm{~nm}$ is generally attributed to electronic transitions from $4 \mathrm{~d}^{10}$ to $4 \mathrm{~d}^{9} 5 \mathrm{~s}^{1}$ of highly dispersed $\mathrm{Ag}^{+}$ions [37-39]. The bands observed at 260 and $286 \mathrm{~nm}$ are assigned to $\mathrm{Ag}_{\mathrm{n}}{ }^{\delta+}$ clusters 
$(2 \leq \mathrm{n} \leq 4)[40]$. The absorption at wavelengths $>390 \mathrm{~nm}$ is attributed to nanoparticles of metallic silver $\left(\mathrm{Ag}_{\mathrm{m}}{ }^{0}\right)$ [38]. Intensity of the band at $225 \mathrm{~nm}$ is higher for $\mathrm{Ag}_{3.0} \mathrm{AlSiBEA}(100)$ zeolite, whereas bands at 260 and $286 \mathrm{~nm}$ are more intensive on $\operatorname{Ag}_{3.0} \operatorname{AlSiBEA}(200)$ spectrum, which may indicate that $\mathrm{Ag}_{3.0} \mathrm{AlSiBEA}(100)$ contains more $\mathrm{Ag}^{+}$ions and less $\mathrm{Ag}_{\mathrm{n}}{ }^{\delta+}$ clusters than $\mathrm{Ag}_{3.0} \mathrm{AlSiBEA}(200)$. It is likely that some silver ions remain incorporated in the framework of partially dealuminated zeolite even after the SCR-process. Higher amount of $\mathrm{Ag}^{+}$ions in $\mathrm{Ag}_{3.0} \mathrm{AlSiBEA}(100)$ explains greater increase of Lewis acidity upon introduction of silver in $\operatorname{AlSiBEA(100)~than~AlSiBEA(200)~(Fig.~S1~in~Supplementary~material),~since~silver~ions~act~as~}$ Lewis acids.

The presence of well dispersed oxidized silver species in $\operatorname{AgAlSiBEA}(100)$ and $\operatorname{AgAlSiBEA(200)}$ is confirmed by XPS (Fig. S2 in Supplementary material). Peak at binding

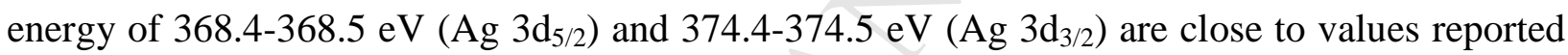
earlier for silver well dispersed in zeolites [41,42].

Nanoparticles of silver with the average size of 8-9 $\mathrm{nm}$ were detected on TEM images of $\mathrm{Ag}_{3.0} \mathrm{AlSiBEA}(100)$ and $\mathrm{Ag}_{3.0} \mathrm{AlSiBEA}(200)$ zeolites after pre-treatment in the conditions of $\mathrm{H}_{2^{-}}$ promoted SCR of NO with ethanol (Fig. S3 in Supplementary material). The interplanar spacing equal to $3.958 \AA$ for $\operatorname{Ag}_{3.0} \operatorname{AlSiBEA}(100)$ and $3.943 \AA$ for $\operatorname{Ag}_{3.0} \operatorname{AlSiBEA}(200)$ can be attributed to the $\mathrm{d}_{302}$ spacing of BEA zeolite, which corroborate the XRD results. For $\mathrm{Ag}_{3.0} \mathrm{AlSiBEA}(100)$, $\mathrm{d}_{\mathrm{hkl}}$ spacing, equal to $1.141,2.051$ and $2.802 \AA$, can be attributed to (222), (200) planes of the face-centred cubic metallic silver and (111) plane of $\mathrm{Ag}_{2} \mathrm{O}$, respectively. Diffraction rings on pattern of $\operatorname{Ag}_{3.0} \operatorname{AlSiBEA}(200)$ (with $\mathrm{d}_{\mathrm{hkl}}$ of 0.800 and $1.154 \AA$ ) can be assigned to (331) and (222) planes of the face-centred cubic metallic silver and (211) plane of $\mathrm{Ag}_{2} \mathrm{O}\left(\mathrm{d}_{\mathrm{hkl}}=1.934 \AA\right)$.

\subsection{Catalytic properties of AgAISiBEA zeolites}

Figures 8 A, B show the temperature dependences of NO conversion in the SCR with ethanol on $\operatorname{AgAlSiBEA}(100)$ and $\operatorname{AgAlSiBEA}(200)$ zeolite catalysts. It should be noted that $\mathrm{N}_{2} \mathrm{O}$, the undesirable by-product of the SCR of $\mathrm{NO}$ reaction (due to its large greenhouse gas 
potential) was not formed in the conditions of the catalytic experiments. The SCR-activity of $\operatorname{AlSiBEA}(100)$ and $\operatorname{AlSiBEA}(200)$ supports is low, i.e., NO conversion does not exceed $10 \%$ in all temperature range of the reaction (curves 1,5 ). The maximally achieved NO-to- $\mathrm{N}_{2}$ conversion at $725 \mathrm{~K}$ after the introduction of $0.5,1.5$ and $3.0 \mathrm{wt} \%$ of $\mathrm{Ag}$ in $\mathrm{AlSiBEA}(100)$ is equal to 12,24 and $36 \%$, respectively (Fig. 8A, curves 2-4).

For AlSiBEA(200)-based samples, NO conversion increases to 24 and $26 \%$ at $625 \mathrm{~K}$ after the incorporation of 1.5 and $3.0 \mathrm{wt} \%$ of silver and almost the same for $\mathrm{Ag}_{0.5} \mathrm{AlSiBEA}(200)$ and AlSiBEA(200) catalysts (Fig. 8B). Conversion of ethanol to $\mathrm{CO}_{2}, \mathrm{CO}$ and ethylene in the SCR-process is shown in Fig. 9. When silver loading is increased from 0.5 to $3.0 \mathrm{wt} \%$ in both $\operatorname{AgAlSiBEA}(100)$ and $\mathrm{AgAlSiBEA}(200)$ catalysts, ethanol conversion to $\mathrm{CO}_{2}$ is enhanced (curve 1) and to $\mathrm{CO}$ and ethylene is notably decreased (curves 2, 3). Obviously, at higher Ag content ethanol activation by oxidation on silver species predominates over dehydration on acidic sites, which leads to higher NO-to- $\mathrm{N}_{2}$ conversion (Fig. 8). The main C-containing product during the SCR of $\mathrm{NO}$ on $\mathrm{Ag}_{3.0} \mathrm{AlSiBEA}(100)$ and $\mathrm{Ag}_{3.0} \mathrm{AlSiBEA}(200)$ is $\mathrm{CO}_{2}$, however for the catalyst with higher concentration of acidic sites $(\mathrm{Si} / \mathrm{Al}=100)$ ethylene is observed in the reaction products up to $675 \mathrm{~K}$. Decrease in ethanol conversion to ethylene with temperature rising for all catalysts may be caused by less rate of $\mathrm{C}_{2} \mathrm{H}_{5} \mathrm{OH}$ dehydration with $\mathrm{C}_{2} \mathrm{H}_{4}$ formation and/or by ethylene participation in the SCR of NO. Thus, on $\operatorname{Ag}_{1.5} \operatorname{AlSiBEA}(200)$ (Fig. 9, curve 3) sharp decrease in ethanol conversion to $\mathrm{C}_{2} \mathrm{H}_{4}$ is observed at $625 \mathrm{~K}$, when the maximal NO conversion is achieved (Fig. 8, curve 7).

Almost the same NO conversion is achieved for samples with different degree of dealumination and equal Ag content at temperatures up to $625 \mathrm{~K}$ (Fig. 8). However at higher temperatures $(>625 \mathrm{~K}) \quad \mathrm{NO}$ conversion on $\operatorname{AgAlSiBEA}(100)$ still increases and on $\operatorname{AgAlSiBEA}(200)$ decreases. Apparently, in the presence of sample with lower Brønsted and Lewis acidity the rate of reductant oxidation by $\mathrm{O}_{2}$ is increased with temperature rising and participation of ethanol in reduction of NO is decreased. 
Role of silver species $\left(\mathrm{Ag}^{+}\right.$cations and $\mathrm{Ag}_{\mathrm{n}}{ }^{+}$clusters $)$consists in the activation of alcohols, adsorbed on silver LAS, by their partial oxidation with formation of more reactive intermediates (enolic species) [18,20,43]. Activation of $\mathrm{NO}_{\mathrm{x}}$ occurs on Lewis acidic sites [44]. In the presence of $\operatorname{AgAlSiBEA(100),~containing~higher~amount~of~acidic~sites~on~which~enolic~and~}$ nitrate intermediates are adsorbed, with temperature rising the rate of NO SCR is increased.

The increasing of NO conversion in the SCR with ethanol after hydrogen addition is observed from $10 \%$ to $26 \%$ on $\operatorname{Ag}_{0.5} \operatorname{AlSiBEA}(100)$, from $24 \%$ to $50 \%$ in the presence of $\operatorname{Ag}_{1.5} \operatorname{AlSiBEA}(100)$ and for $\operatorname{Ag}_{3.0} \operatorname{AlSiBEA}(100)$ - from $34 \%$ to $56 \%$ at $675 \mathrm{~K}$ (Fig. 8A). The effect of hydrogen is less significant for AlSiBEA(200)-based samples, namely, NO conversion increased from $6 \%$ to $17 \%$ on $\operatorname{Ag}_{0.5} \operatorname{AlSiBEA}(200)$, from $23 \%$ to $28 \%$ on $\operatorname{Ag}_{1.5} \operatorname{AlSiBEA}(200)$ and from $25 \%$ to $40 \%$ on $\operatorname{Ag}_{3.0} \operatorname{AlSiBEA}(200)$ (Fig. 8B). $\mathrm{H}_{2}$ effect on the SCR-process on AgAlSiBEA catalysts is reversible - after removal of hydrogen from the gas feed, conversion of NO is decreased to the value achieved before $\mathrm{H}_{2}$ addition. Moreover, hydrogen is not a selective reductant of NO (reduction does not occur in the absence of ethanol in the reaction mixture).

Therefore, it seems that level of $\mathrm{H}_{2}$-promoting effect depends on both silver loading and zeolite component of the catalyst; and higher effect is observed for the catalysts with lower $\mathrm{Si} / \mathrm{Al}$ ratio. This assumption is supported by our previous investigations [20], i.e., promoting $\mathrm{H}_{2}$-effect on the SCR of NO with ethanol was observed in the presence of $\operatorname{AgAlBEA}(12.5)$ catalysts, whereas was almost absent on $\operatorname{AgSiBEA(1000).~Fig.~} 10$ shows increase in NO conversion after hydrogen addition in the presence of the silver-containing BEA zeolites with different $\mathrm{Si} / \mathrm{Al}$ ratio. This Figure reveal an extreme dependence of $\mathrm{H}_{2}$-effect on silica/alumina ratio, i.e., the promoting effect is enhanced when $\mathrm{Si} / \mathrm{Al}$ increase from 12.5 to 100 and then diminish with further increase of this ratio. This tendency may be caused by the similar change of the concentration of Lewis acidic sites, which are present in studied BEA supports as a result of silver introduction in the zeolites. 
The addition of hydrogen in the reaction mixture changes the distribution of ethanol conversion products in the SCR of NO (Fig. 9, curves marked with asterisks). For all catalysts, $\mathrm{CO}_{2}$ content is increased and amount of products of partial oxidation $(\mathrm{CO})$ and dehydration (ethylene) is decreased in $\mathrm{H}_{2}$ presence. The most noticeable changes are observed on $\mathrm{Ag}_{1.5} \mathrm{AlSiBEA}(100)$ : ethanol conversion to $\mathrm{CO}_{2}$ is increased from 15 to $56 \%$ with simultaneous decreasing to $\mathrm{C}_{2} \mathrm{H}_{4}$ in the temperature range of the reaction. It should be underlined that in the presence of $\mathrm{Ag}_{1.5} \mathrm{AlSiBEA}(100)$ the highest enhancement of $\mathrm{NO}$ conversion is observed after $\mathrm{H}_{2}$ addition (Fig. 8A, curves $3,3^{*}$ ). Thus, in the conditions of our experiments hydrogen addition increases the rate of ethanol oxidation, while simultaneously inhibits the process of ethanol dehydration. The similar effect of promotion of ethanol partial oxidation and suppression of ethanol dehydration and dehydrogenation was observed for the SCR process after hydrogen addition on $\mathrm{Ag} / \mathrm{Al}_{2} \mathrm{O}_{3}$ [45].

Promotion of SCR process with $\mathrm{H}_{2}$ may be caused by the formation of peroxide-like species on silver clusters after dissociation of hydrogen with subsequent formation of $\mathrm{H}-\mathrm{Ag}_{4}{ }^{2+}-$ $\mathrm{H}$, where activation of $\mathrm{O}_{2}$ occurs, followed by formation of hydrogen peroxide species (HOO$\left.\mathrm{Ag}_{4}{ }^{2+}-\mathrm{H}\right)$ [11]. During the reaction of reductant molecules with $\mathrm{HOO}^{-}$partially oxidized intermediates are formed. The suggestion that role of hydrogen in the mechanistic pathways of the SCR process consists in the generation of highly reactive hydroxyl and hydroperoxy species is supported by the fact of increasing NO conversion in the SCR with decane after addition of hydrogen peroxide [46].

Furthermore, in the presence of $\mathrm{H}_{2}$ in the reaction mixture the stability of surface nitrate species is strongly decreased and they are readily transformed on silver sites to the reactive nitrite complexes [8,47-50]. However if only the activation of reagents with formation of more reactive intermediates (enolic and/or nitrite) on silver clusters was a reason of hydrogen promoting effect, the same increase in NO conversion would be observed on both $\operatorname{AgAlSiBEA}(100)$ and $\operatorname{AgAlSiBEA}(200)$. 
We can assume that the presence of Lewis acidic sites on the catalyst surface is necessary to $\mathrm{H}_{2}$-effect occurrence in the SCR of NO. It was shown recently ${ }^{51}$ that for $\mathrm{H}_{2}$ activation on $\theta$ $\mathrm{Al}_{2} \mathrm{O}_{3}(110)$-supported $\mathrm{Ag}$ clusters the interfacial cooperative mechanism between the $\mathrm{Ag}$ cluster and Lewis acid-base pair site (Al-O site) is relevant, because $\mathrm{H}_{2}$ dissociation at the silveralumina interface is thermodynamically preferred compared with silver clusters. The reason of greater promoting effect on partially dealuminated $\operatorname{AgAlSiBEA}(100)$ with higher LAS content than $\operatorname{AgAlSiBEA}(200)$ may be connected with enhanced $\mathrm{H}_{2}$ activation. Alternatively, the higher surface concentration of nitrite-nitrate species adsorbed on Lewis acidic sites of $\operatorname{AgAlSiBEA}(100)$ is sufficient to react with products of ethanol activation. For the $\operatorname{AgAlSiBEA}(200)$ catalysts with lower LAS concentration higher rate of reagents activation in the presence of hydrogen may be annihilated by their deficient surface concentration.

Thus, the design of active Ag-containing catalysts for the $\mathrm{H}_{2}$-promoted SCR process should include creation of two types of active sites - silver nanoclusters and Lewis acidic sites with the optimal concentration on the surface.

\section{Conclusions}

The two-step postsynthesis method used in this work allows obtaining BEA zeolites with different degree of dealumination (with Si/Al ratio of 100 and 200) without lost of their crystallinity and incorporating Ag ions into the vacant $\mathrm{T}$ atom sites of the zeolite framework.

Introduction of silver in partially dealuminated zeolite leads to the formation of new Lewis acidic sites as shown by FT-IR spectroscopy with adsorption of pyridine and CO. Increase in concentration of Lewis acidic sites after silver addition (3.0 wt \%) in AlSiBEA $(\mathrm{Si} / \mathrm{Al}=100)$ is greater than in AlSiBEA (Si/Al=200).

The presence of well dispersed silver species (silver ions incorporated in the framework of the zeolites, small $\operatorname{Ag}_{n}{ }^{\delta+}$ clusters $(2 \leq n \leq 4)$ and nanoparticles with the average size of $\left.8-9 \mathrm{~nm}\right)$ in AgAlSiBEA samples is evidenced by combined use of diffuse reflectance UV-vis, XPS and TEM. 
The temperature range of increasing conversion of NO in the SCR process with ethanol on $\operatorname{AgAlSiBEA}(100)$ catalysts is wider compared to $\operatorname{AgAlSiBEA(200).~This~may~be~caused~by~}$ the excess of rate of deep reductant oxidation by $\mathrm{O}_{2}$ over selective $\mathrm{NO}$ reduction with temperature rising above $625 \mathrm{~K}$ in the presence of sample with lower Brønsted and Lewis acidity.

Level of $\mathrm{H}_{2}$-promoting effect on the process of SCR of $\mathrm{NO}$ with ethanol depends on the dealumination degree of Ag-containing BEA zeolite catalysts and greater effect is observed for the catalysts with higher concentration of surface acidic sites.

\section{References}

[1] B. Moden, J.M. Donohue, W.E. Cormier, H.-X. Li, Top. Catal. 53 (2010) 1367.

[2] J. Janas, S. Dzwigaj, Catal. Today 176 (2011) 272.

[3] L. Li, N. Guan, Microporous Mesoporous Mater. 117 (2009) 450.

[4] B. Gil, J. Janas, E. Włoch, Z. Olejniczak, J. Datka, B. Sulikowski, Catal. Today 137 (2008) 174.

[5] S. Satokawa, Chem. Lett. 29 (2000) 294.

[6] J.P. Breen, R. Burch, Top. Catal. 39 (2006) 53.

[7] S.T. Korhonen, A.M. Beale, M.A. Newton, B.M. Weckhuysen, J. Phys. Chem. C 115 (2011) 885 .

[8] M.M. Azis, H. Härelind, D. Creaser, Catal. Sci. Technol. 5 (2015) 296.

[9] K. Shimizu, M. Tsuzuki, K. Kato, S. Yokota, K. Okumura, A. Satsuma. J. Phys. Chem. C $111(2007) 950$.

[10] K. Shimizu, K. Sugino, K. Kato, S. Yokota, K. Okumura, A. Satsuma, J. Phys. Chem. C, $111(2007) 6481$.

[11] K. Shimizu, K. Sawabe, A. Satsuma, Catal.Sci.Technol.1 (2011) 331.

[12] Y. B. Yu, H. He, X. L. Zhang, H. Deng, Catal.Sci.Technol. 4 (2014) 1239. 
[13] R. Burch, J.P. Breen, C.J. Hill, B. Krutzsch, B. Konrad, E. Jobson, L. Cider, K. Eranen, F. Klingstedt, L-E. Lindfors, Top. Catal. 30-31 (2004) 19.

[14] P. Sazama, L. Čapek, H. Drobná, Z. Sobalık, J. Dědeček, K. Arve, B. Wichterlová, J. Catal. 232 (2005) 302.

[15] K. Eranen, F. Klingstedt, K. Arve, L.E. Lindfors, D.Y. Murzin, J. Catal. 227 (2004) 328.

[16] J. Shibata, Y. Takada, A. Shichi, S. Satokawa, A. Satsuma, T. Hattori, Appl. Catal., B 54 (2004) 137.

[17] A. Sultana, M. Haneda, T. Fujitani, H. Hamada, Catal. Lett. 114 (2007) 96.

[18] Y. Yan, Y. Yu, H. He, J. Zhao, J. Catal. 293 (2012) 13.

[19] P. Kyriienko, N. Popovych, S. Soloviev, S. Orlyk, S. Dzwigaj, Appl. Catal., B. 140-141 (2013) 691 .

[20] N. Popovych, P. Kyriienko, S. Soloviev, S. Orlyk, S. Dzwigaj, Microporous Mesoporous Mater. 203 (2015) 163.

[21] S. Dzwigaj, M.J. Peltre, P. Massiani, A. Davidson, M. Che, T. Sen, S. Sivasanker, Chem. Commun. 1 (1998) 87.

[22] S. Dzwigaj, M. Matsuoka, R. Franck, M. Anpo, M. Che, J. Phys. Chem. B 102 (1998) 6309.

[23] S. Dzwigaj, Curr. Opin. Solid State Mater. Sci. 7 (2003) 461.

[24] S. Dzwigaj, E. Ivanova, R. Kefirov, K. Hadjiivanov, F. Averseng, J.M. Krafft, M.Che, Catal. Today 142 (2009) 185.

[25] S. Dzwigaj, Y. Millot, J.-M. Krafft, N. Popovych, P. Kyriienko, J. Phys. Chem. C 117 (2013) 12552.

[26] S. Dzwigaj, N. Popovych, P. Kyriienko, J.-M. Krafft, S. Soloviev, Microporous Mesoporous Mater. 182 (2013) 16.

[27] M.A. Camblor, A. Corma, J. Pérez-Pariente, Zeolites 13 (1993) 82.

[28] J.S. Reddy, A. Sayari, Stud. Surf. Sci. Catal. 94 (1995) 309. 
[29] S. Dzwigaj, P. Massiani, A. Davidson, M. Che, J. Mol. Catal. A 155 (2000) 169.

[30] E. Bourgeat Lami, F. Fajula, D. Anglerot, T. Des Courieres, Microporous Mater. 1 (1993) 237.

[31] K. Hadjiivanov, A. Penkova, R. Kefirov, J. Janas, A. Plesniar, S. Dzwigaj, M. Che, Microporous Mesoporous Mater. 131 (2010) 1.

[32] K. Chakarova, K. Hadjiivanov, J. Phys. Chem. C 115 (2011) 4806.

[33] K. Hadjiivanov, G. Vayssilov, Adv. Catal. 47 (2002) 307.

[34] K. Hadjiivanov, A. Penkova, M. Centeno, Catal. Commun. 8 (2007) 1715.

[35] B.H. Chiche, F. Fajula, E. Garrone, J. Catal. 146 (1994) 460.

[36] B. Gil, S.I. Zones, S-J. Hwang, M. Bejblova, J. Čejka. J. Phys. Chem. C 112 (2008) 2997.

[37] K.A. Bethke, H.H. Kung, J. Catal. 93 (1997) 172.

[38] N. Bogdanchikova, F.C. Meunier, M. Avalos-Borja, J.P. Breen, A. Pestryakov, Appl. Catal., B 36 (2002) 287.

[39] A. Satsuma, J. Shibata, A. Wada, Y. Shinozaki, T. Hattori, Stud. Surf. Sci. Catal. 145 (2003) 235.

[40] J. Shibata, Y. Takada, A. Shichi, S. Satokawa, A. Satsuma, T. Hattori, J. Catal. 222 (2004) 368 .

[41] N. D. Hutson, B. A. Reisner, R. T. Yang, B. H. Toby, Chem. Mater. 12 (2000) 3020.

[42] W. Ju, M. Matsuoka, K. Iino, H. Yamashita, M. Anpo, J. Phys. Chem. B 108 (2004) 2128.

[43] H. He, Y. Li, X. Zhang, Y. Yu, C. Zhang, Appl. Catal. A 375 (2010) 258.

[44] X. Zhang, H. He, H. Gao, Y. Yu, Spectrochim. Acta, Part A 71 (2008) 1446.

[45] Y. Yu, Y. Li, X. Zhang, H. Deng, H. He, Y. Li, Environ. Sci. Technol. 49 (2015) 481.

[46] P. Sazama, B. Wichterlova, Chem. Commun. 38 (2005) 4810.

[47] C. Thomas, Appl. Catal., B 162 (2015) 454-462.

[48] H. Kannisto, H.H. Ingelsten, M. Skoglundh, Top. Catal. 52 (2009) 1817. 
[49] N. A. Sadokhina, A. V. Bukhtiyarov, A. I. Mytareva, R. I. Kvon, V. I. Bukhtiyarov, A. Yu. Stakheev, Top Catal. 56 (2013) 187.

[50] K. Shimizu, J. Shibata, A. Satsuma, J. Catal. 239 (2006) 402.

[51] P. Hirunsit, K. Shimizu, R. Fukuda, S. Namuangruk, Y. Morikawa, M. Ehara, J. Phys. Chem. C 118 (2014) 7996. 


\section{Figure captions}

Fig. 1 XRD patterns recorded at room temperature.

Fig. 2 FT-IR spectra recorded at room temperature of the samples calcined at $773 \mathrm{~K}(3 \mathrm{~h})$ in flowing air and then outgassed at $573 \mathrm{~K}\left(10^{-3} \mathrm{~Pa}, 2 \mathrm{~h}\right)$.

Fig. 3 FT-IR difference spectra $(\mathrm{OH}$ stretching region) of samples after adsorption of $\mathrm{CO}$ at $100 \mathrm{~K}$ : equilibrium $\mathrm{CO}$ pressure of $100 \mathrm{~Pa}$ (a) and development of the spectra during evacuation for about $0.5 \mathrm{~h}$ at $100 \mathrm{~K}$ up to $10^{-3} \mathrm{~Pa}(\mathrm{~b}-\mathrm{f})$.

Fig. 4 FT-IR difference spectra (carbonyl stretching region) of $\mathrm{CO}$ adsorbed at $100 \mathrm{~K}$ on samples: equilibrium $\mathrm{CO}$ pressure of $100 \mathrm{~Pa}$ (a) and development of the spectra during evacuation for about $0.5 \mathrm{~h}$ at $100 \mathrm{~K}$ up to $10^{-3} \mathrm{~Pa}(\mathrm{~b}-\mathrm{f})$. The spectra are background corrected.

Fig. 5 FT-IR difference spectra recorded at room temperature of the samples after calcination at $773 \mathrm{~K}$ for $1 \mathrm{~h}$ in $\mathrm{O}_{2}\left(2 \cdot 10^{4} \mathrm{~Pa}\right)$, outgassing at $673 \mathrm{~K}\left(10^{-3} \mathrm{~Pa}\right)$ for $1 \mathrm{~h}$, adsorption of pyridine at $423 \mathrm{~K}$ and desorption of pyridine at $423 \mathrm{~K}$ (a), $573 \mathrm{~K}$ (b), $673 \mathrm{~K}$ (c).

Fig. 6 FT-IR difference spectra recorded at room temperature of the samples after reduction at $773 \mathrm{~K}$ for $1 \mathrm{~h}$ in $\mathrm{H}_{2}$ flow, outgassing at $673 \mathrm{~K}\left(10^{-3} \mathrm{~Pa}\right)$ for $1 \mathrm{~h}$, adsorption of pyridine and desorption $423 \mathrm{~K}$.

Fig. 7 DR UV-Vis spectra of the samples after pre-treatment in the conditions of the SCRprocess.

Fig. 8 Temperature dependences of NO conversion in the SCR with ethanol (*- in the presence of $\mathrm{H}_{2}$ in the reaction mixture) on: (A) $1-\operatorname{AlSiBEA}(100), 2-\operatorname{Ag}_{0.5} \operatorname{AlSiBEA}(100)$, $3-\operatorname{Ag}_{1.5} \operatorname{AlSiBEA}(100), 4-\operatorname{Ag}_{3.0} \operatorname{AlSiBEA}(100), \quad(\mathrm{B}) 5-\operatorname{AlSiBEA}(200)$, $6-\operatorname{Ag}_{0.5} \operatorname{AlSiBEA}(200), 7-\operatorname{Ag}_{1.5} \operatorname{AlSiBEA}(200), 8-\operatorname{Ag}_{3.0} \operatorname{AlSiBEA}(200)$.

Fig. 9 Temperature dependences of ethanol conversion in the SCR of NO to $\mathrm{CO}_{2}(1-\mathbf{-}-\square-)$, $\mathrm{CO}(2-\bullet-0-)$ and $\mathrm{C}_{2} \mathrm{H}_{4}(3-\Delta-\Delta-)\left(*-\right.$ in the presence of $\mathrm{H}_{2}$ in the reaction mixture).

Fig. 10 Dependence of increase in NO conversion in the SCR process on the Si/Al ratio of AgBEA catalysts after $\mathrm{H}_{2}$ addition. 

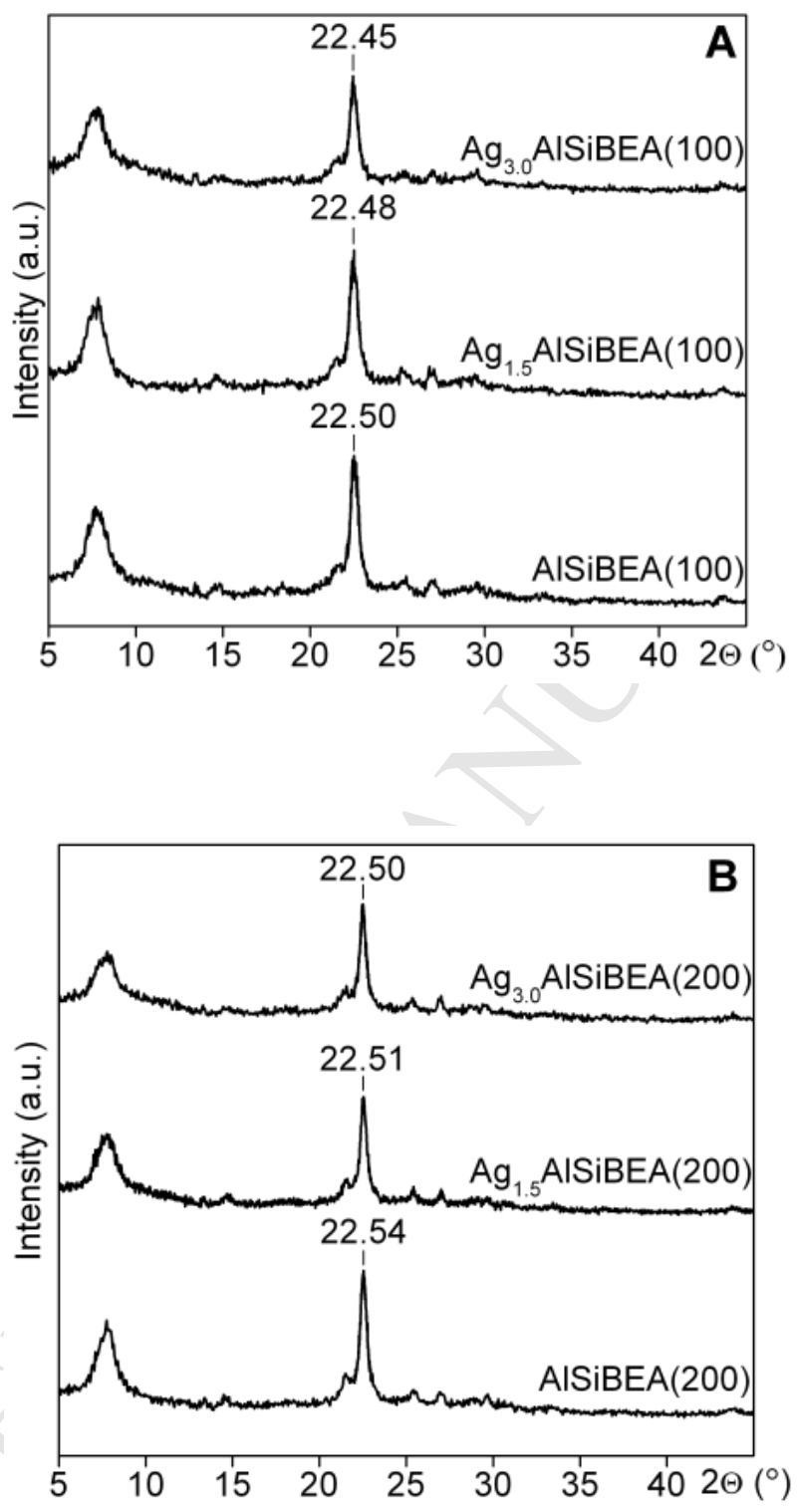

Fig. 1. 


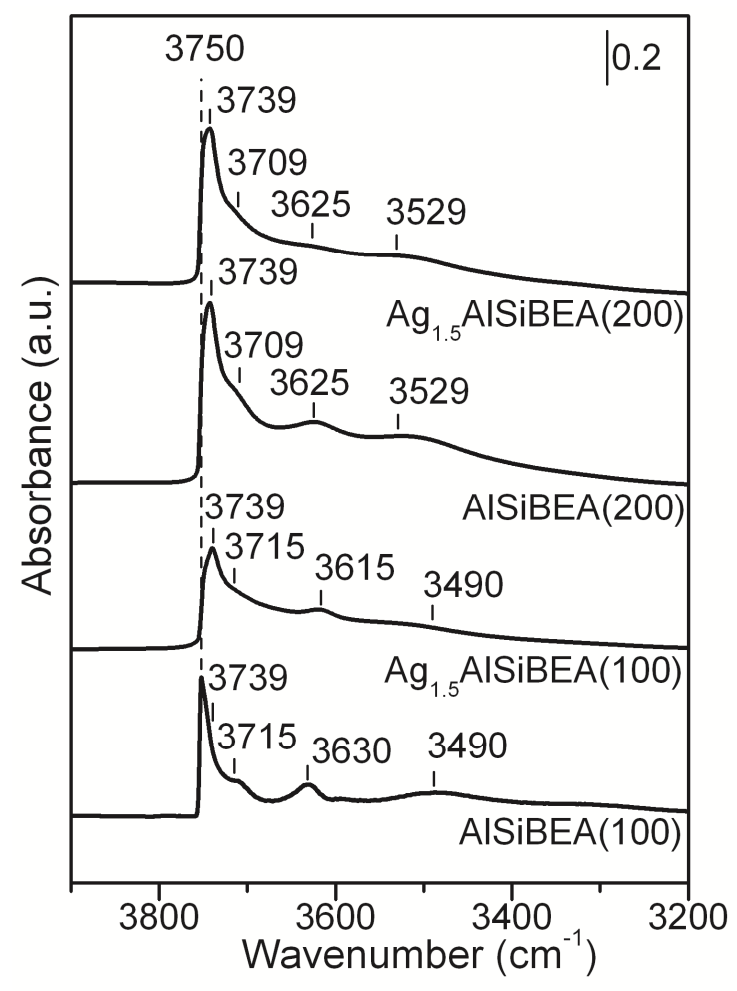

Fig. 2. 

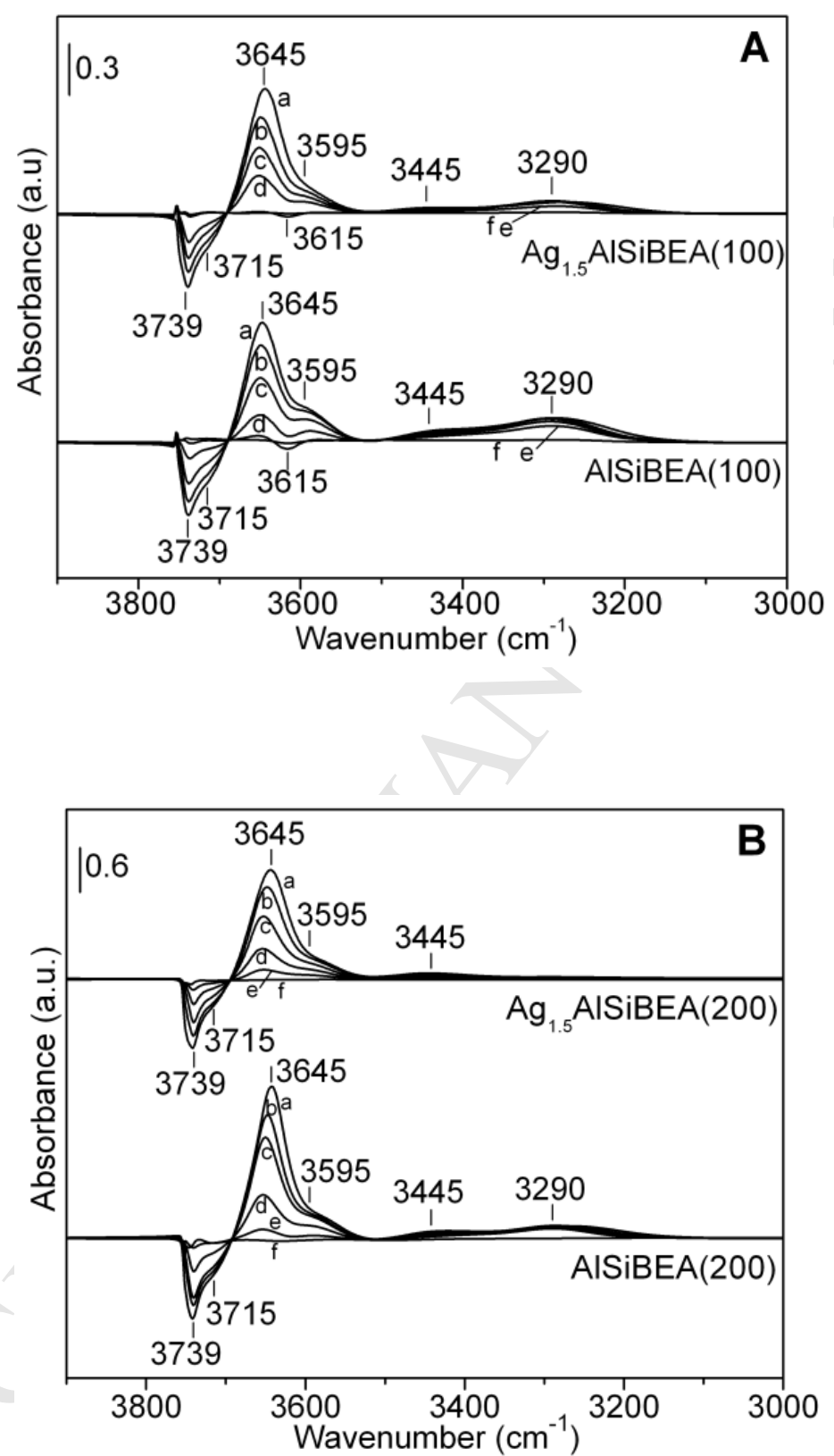

Fig. 3. 

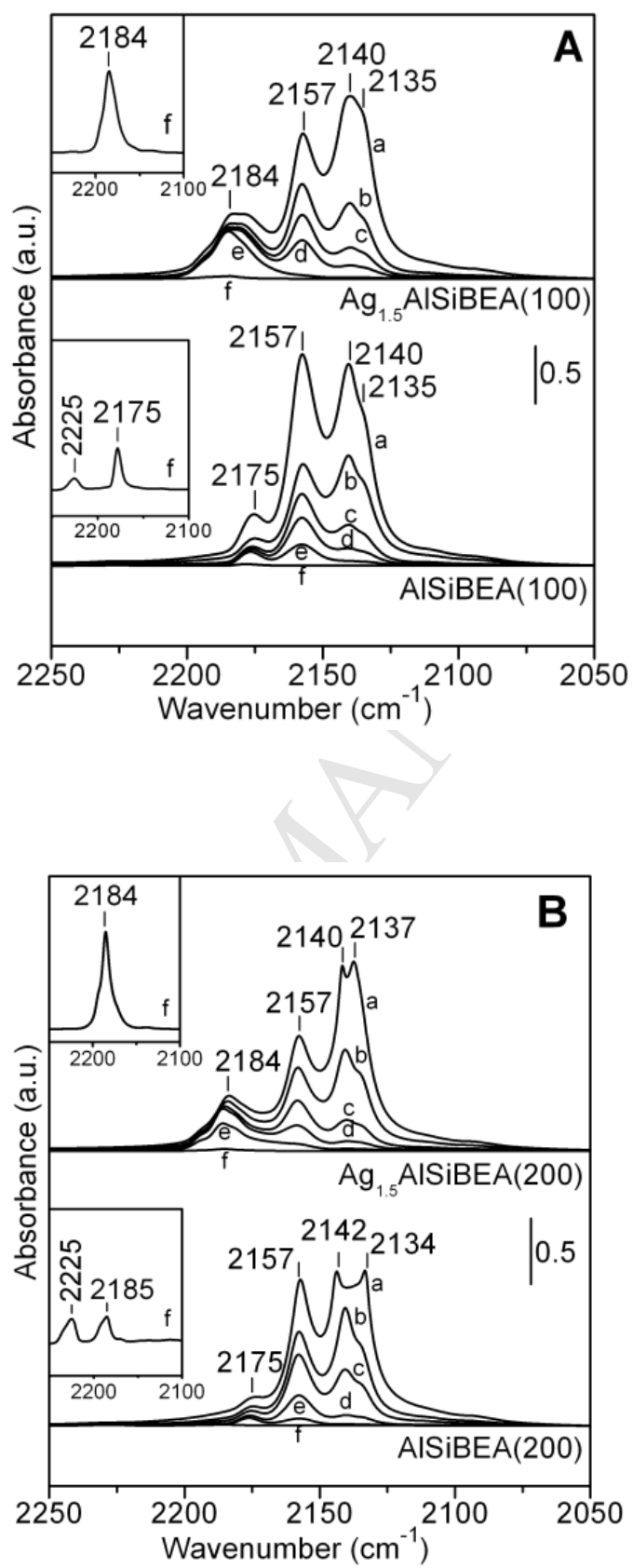

Fig. 4. 

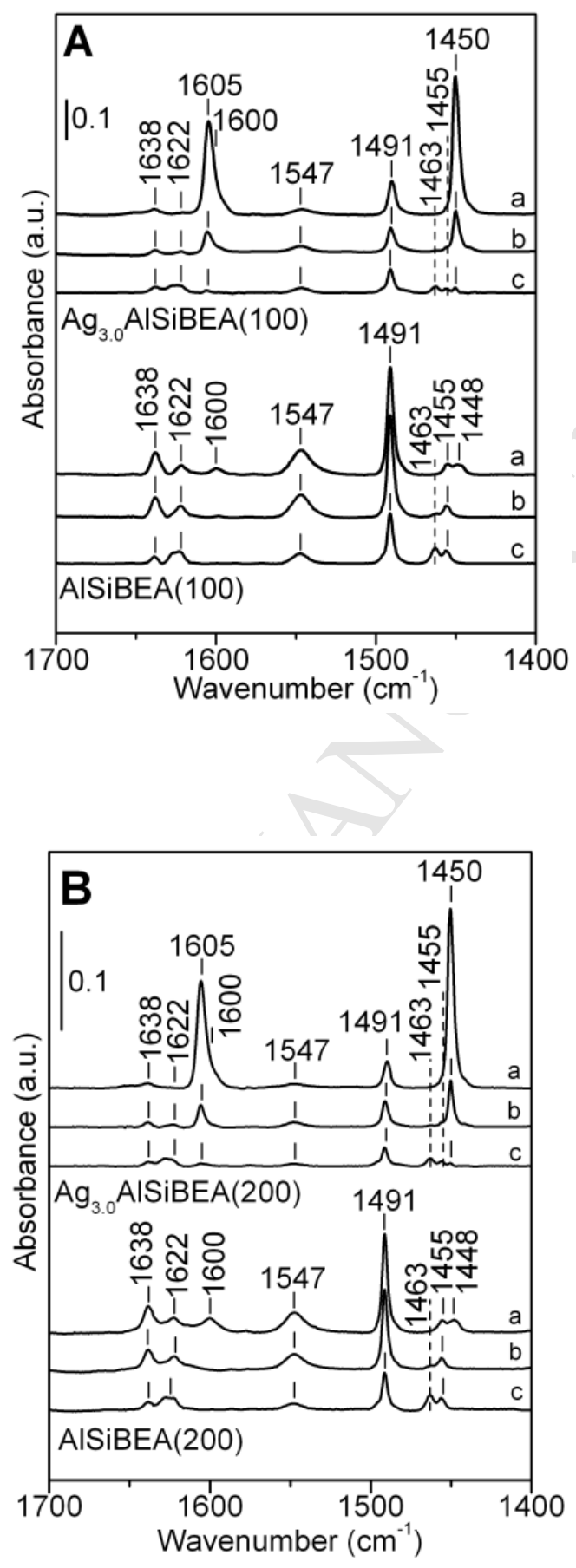

Fig. 5. 


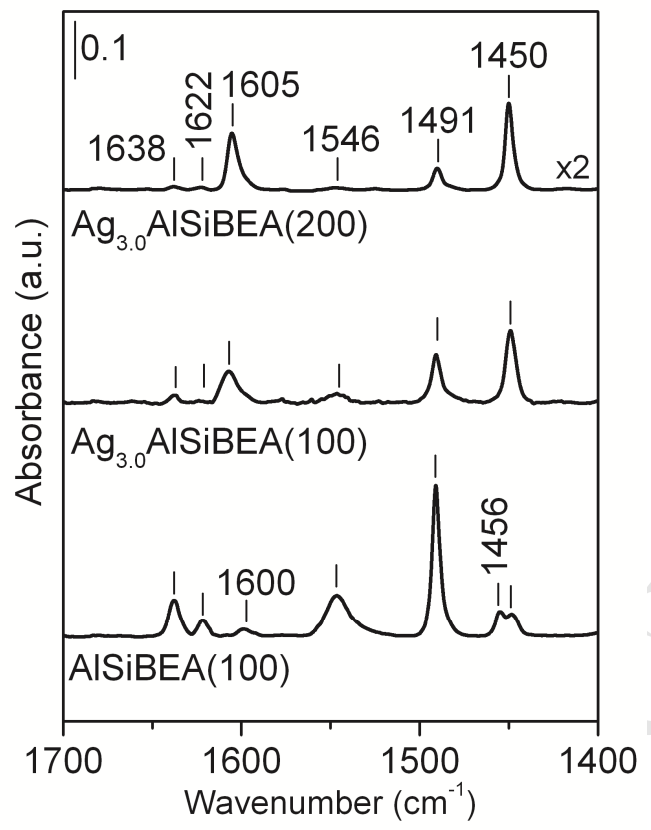

Fig. 6.

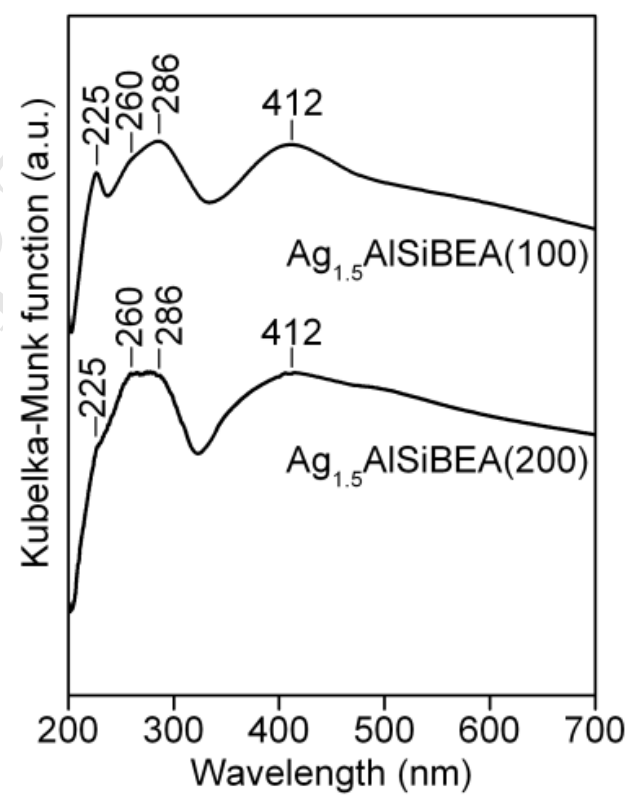

Fig. 7. 

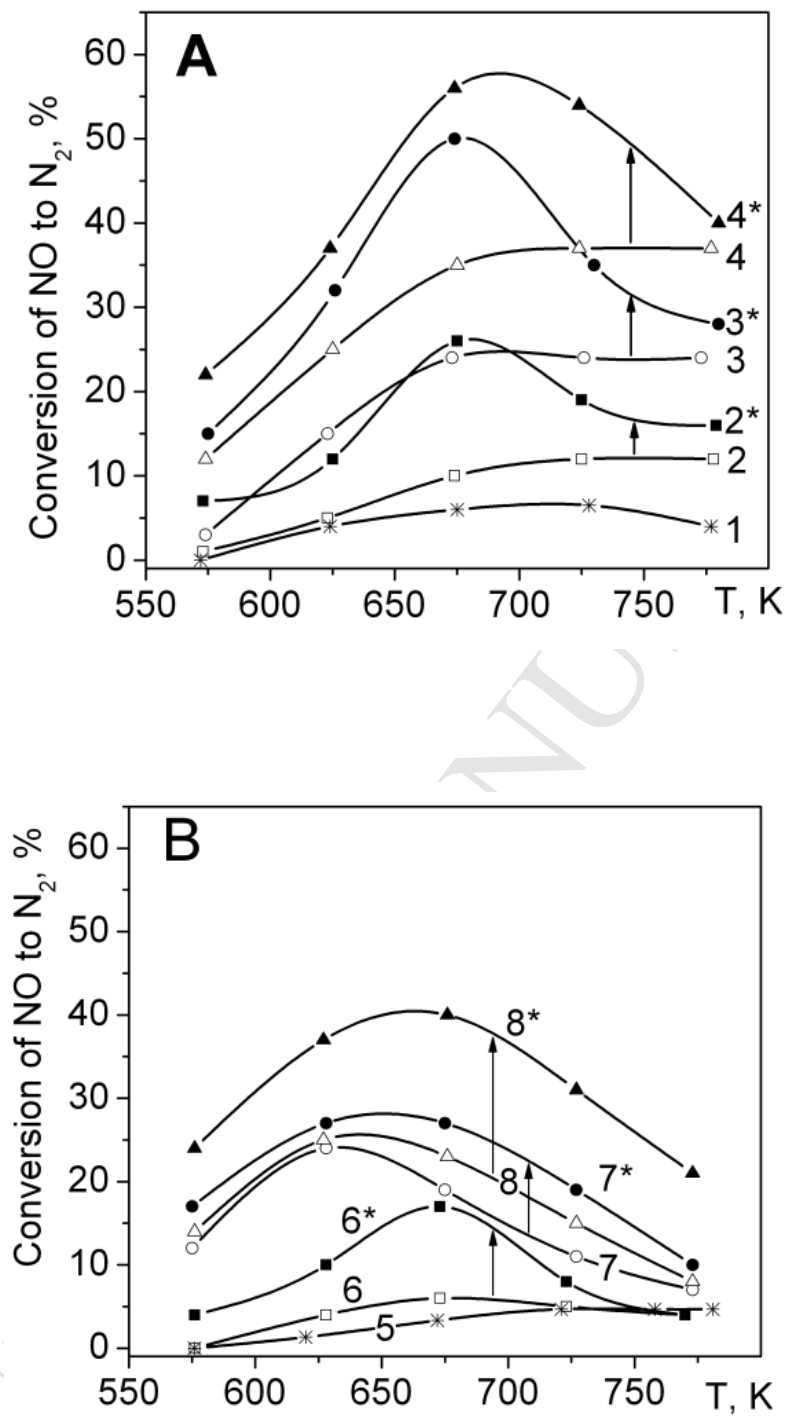

Fig. 8. 

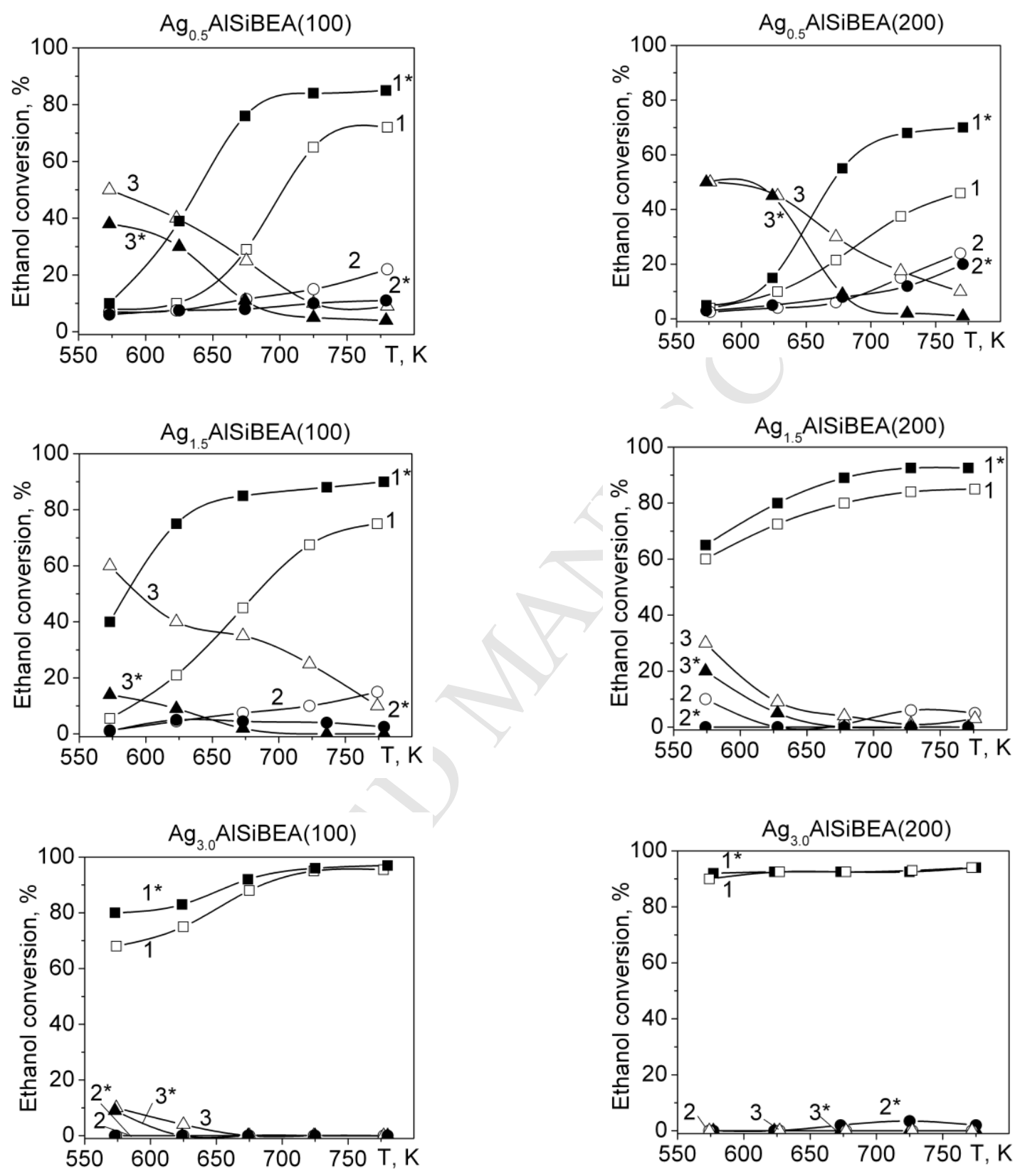

Fig. 9. 


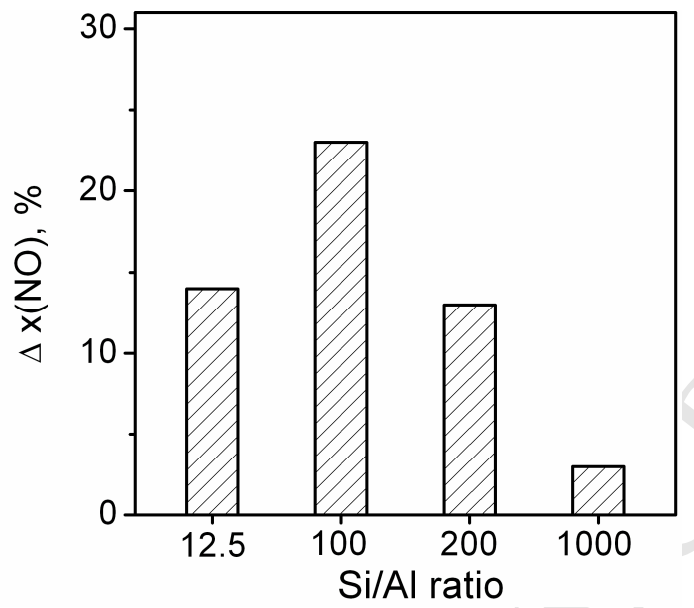

Fig. 10. 
- Two-step postsynthesis allowed obtaining catalysts with Si/Al ratio of 200 and 100.

- $\mathrm{H}_{2}$-promoting effect on the SCR of NO depended on dealumination degree of zeolite.

- Greater $\mathrm{H}_{2}$-effect observed on catalysts with higher amount of acidic sites. 